\title{
KAMU KURUMLARINDA ÖRGÜTSEL DEDİKODU VE İŞYERİ YALNIZLIĞINA DAİR BİR ARAŞTIRMA
}

\author{
Hale Eda AKDURU \\ İstanbul Üniversitesi, İşletme Fakültesi, (geceeda @ gmail.com) \\ Prof. Dr. Fatih SEMERCï̈̈Z \\ İstanbul Üniversitesi, İşletme Fakültesi, (fsemerci@istanbul.edu.tr)
}

\begin{abstract}
ÖZET
Çalışanlar açısından örgütsel dedikodu, kişiler arasındaki ilişkiler temelinde şekillenen ve samimiyet esasına dayalı hızl yayılan bir iletişim şeklidir. Işyeri yalnızlı̆̆ ise çalışanın işyeri ortamında sağllklı ilişkiler kuramaması, iletişim ve ifade konularında başarısız olması temelinde şekillenen bir olgudur. Araştırmamızda işletmelerde örgütsel dedikodu ile işyeri yalnızlığı ile arasındaki ilişki incelenecek olup, bu amaçla Uşak'ta çalışan kamu personelinden oluşturulacak bir örneklem üzerinde anket uygulanıp, örgütsel dedikoduya çalışanların yaklaşımını ölçmek amacıyla Leblebici vd. (2009) tarafindan geliştirilen ölçek ile işyeri yalnızlığına ilişkin Wright vd. (2006) tarafindan geliştirilen 'İ̧̧ Yerinde Yalnızlık Ölçeği' kullanılacak, veriler çeşitli istatistik yöntemlerle analiz edilerek yöneticilere elde edilecek sonuçlara dayalı öneriler geliştirilecektir.
\end{abstract}

Anahtar Kelimeler: Örgütsel Dedikodu, İsyeri Yalnızlığl.

\section{A STUDY ON ORGANISATIONAL GOSSIP AND WORKPLACE LONELINESS AT PUBLIC ENTREPRISES}

\begin{abstract}
Organisational gossip is an easy way of communication stemming from informal relationships between employees. Workplace loneliness has consequences like unhealthy relationships and unsuccessful communications at the workplace. With this study the relationship between organisational gossip and workplace loneliness is going to be researched through a sample chosen from the civil workers at Usak City. 'The Workplace Loneliness Measure' by Wright etc. (2006) and 'Organisational Gossip Measure' by Leblebici etc. (2009) are going to be used at the survey and the data collected is going to be analysed through some statiscal methods to bring suggestions for the managers.
\end{abstract}

Keywords: Organisational Gossip, Workplace Loneliness. 


\section{Giriş}

Toplumun bir parçası olan insan gerek zorunlu gerekse de sosyal ihtiyaçlarını karşılayabilmek adına içerisinde hayatını devam ettirdiği çevre ile etkileşime girmek zorundadır. Bu noktada çeşitli iletişim kanalları aracılığıyla çevresi ile ilişki kuran bireyin, çalışma ortamında çeşitli resmi ve gayri resmi yöntemler ile etkileşimini devam ettirmesi örgütün işleyişini sürdürebilmesi açısından bir zorunluluktur. İletişim kanallarındaki herhangi bir tıkanıklık verilen emir ve talimatların yerine getirilmesinde aksaklıklar yaşanmasına sebebiyet verebilir ve zaman içerisinde bu durum çalışan ve işverenler açısından büyük problemler yaşanmasıyla sonuçlanmaktadır.

Örgüt içerisindeki söz konusu informal iletişim kanallarından birisi olan örgütsel dedikodu çoğu zaman istenmeyen ancak önüne geçilmesi çok kolay olmayan, kişisel ilişkilerin rol aldığı bir aktarım mekanizmasıdır. Örgütsel dedikodu avantaj ve dezavantaj tartışmalarının arasında örgütsel sonuçları açısından araştırmacıların son dönemlerde dikkatini çekmekte olan bir kavram haline gelmiştir. İşyeri yalnızlığı ise örgütsel dedikodunun aksine sosyal ilişkiler konusundaki eksiklik ve yetersizlikler neticesinde ortaya çıkmakta ve örgüt içerisindeki iletişim ağını çoğu zaman olumsuz şekilde etkilemektedir.

Bu çalışmanın amacı ‘Örgütlerde örgütsel dedikodu işyeri yalnızlığı üzerinde etkili midir?’ şeklindeki araştırma sorusunu incelemektir. Örgütsel dedikodu ve işyeri yalnızlığı kavramları arasındaki iliş̧kiye dair literatürde çalışma bulunmaması bizi bu çalışmayı yapmaya yönelten başlıca sebeptir. Örgütsel dedikodunun sonuçları itibariyle işyerinde çalışanları yalnızlığa yöneltmesi veya tam tersi bir etki yaratabilmesi imkân dâhilinde olup, bu durumun örgüt üzerindeki etkileri konusunda da bu çalışmayla çeşitli fikirler ortaya atılmıştır.

Çalışmamız aracılığıyla Uşak Belediyesi bünyesinde faaliyet göstermekte olan firma çalışanları üzerinde örgütsel dedikodu kavramı ile işyeri yalnızlığı arasındaki ilişki incelenmiş olup, belirlenen örneklem üzerinde anket uygulanarak veri toplanmıştır. Toplanan veriler çeşitli istatistikî programlar aracılığıyla analiz edilip bulgulara dönüştürülmüştür. En nihayetinde ise bulgular yorumlanarak çalışma tamamlanmıştır.

\section{Kavramsal Çerçeve Ve Hipotezler}

\section{1. Örgütsel Dedikodu}

Örgütsel iletişim; içinde bilginin hareket ettiği ve örgütçe değişildiği bir süreçtir. Bilgi resmi olmayan ve resmi yapılarda akar ve yukarıdan aşağıya, aşağıdan yukarıya ve yatay olarak hareket eder (Schermerhon vd., 2000:342). Örgütsel dedikodu ise örgütsel iletişimin bir parçasıdır.

Kelime anlamı olarak Türk Dil Kurumu [TDK]'ya göre dedikodu "Başkalarını çekiştirmek ve kınamak üzere yapılan konuşma, kov, gıybet, kılükal"dır (TDK, 2011). Örgütsel dedikodu ise dedikodunun kurumlar içerisine yansımasıyla meydana gelir.

Dedikodunun örgütsel yaşamdaki önemi ilk kez 1993 yılında Noon ve Delbridge tarafından ifade edilmiş ve "örgütsel dedikodu" kavramı öne sürülmüştür (Akdoğan vd., 2009:17). Kurum içinde dedikodu, psiko-sosyal bir ihtiyaçtır. Daha çok üçüncü kişilerle ilgili, egonun ihtiyaçları doğrultusunda gerçekleştirildiği bir çeşit tatmindir (Eroğlu, 2005). Örgüt içerisinde sosyal ağların genişlemesiyle örgütsel dedikodunun kapsamı da genişlemektedir ve engellenmesi güçleşmektedir.

Bireysel açıdan dedikodunun araçsal konumuyla ilgili üç unsur öne çıkmaktadır. Bunlar bilgi, etki ve reklâmdır (Rosnow, 1977). Dedikodu örgüt içerisinde bilgilerin oldukça hızlı akmasını sağlar ve aktarılan mesajlar çalışanlar üzerinde bazen yapıcı bazen de yıkıcı etkiler yaratabilmektedir. Ayrıca dedikodu mekanizmasına dâhil edilen konular -olumlu ya da olumsuz- reklam etkisi yaratmaktadır.

Uygun şekilde yönetilen iletişim ağları, herhangi bir iş ortamında çalışanların moralini düzeltme, kurum içinde sosyalleşmeyi sağlama, grup normları için bir rehber olma gibi örgüte yararlı olabilecek birçok amaca hizmet etmektedir. Dedikodular işe çeşitlilik ve farklılık katarak morali artırmakta ve bu sayede bazı rutin işler bile dayanılır hale gelebilmekte, hatta bir takım ruhu kaynağı olarak kabul edilebilmektedir (Thomas \& Rozell, 2007).

\section{2. İşyeri Yalnızlığı}

Yalnızlık, sözcük olarak başkalarından uzak olma anlamına gelir (Şişman \& Turan, 2004). Ancak bu tanım yalnızlık kavramını tam olarak karşılamaktan uzaktır. Yalnızlık, insanın kendisini anlaşılmamış ve kimsesiz hissettiği durumlardır. Genel anlamda yalnızlık, bireyler arası ilişkilerin ve sosyal etkileşimin niteliğinin zayıf olmasının yarattığı ruh halidir (Ernst \& Cacioppo, 1999). Dolayısıyla bireyler kendilerini kalabalık ortamlarda da yalnız hissedebilmektedirler.

Yalnızlık, ürkütücü, korkutucu, kaygı verici, umutsuzluğa sürükleyen, bireyde gerginlik oluşturan, bireyin yaşamını anlamsızlaştıran, içine kapanık bir kişilik oluşturmasına, yabancılaşmasına, karamsar olmasına neden 
olan ve bireyin sosyalleşmesini engelleyen bir duygu durumudur (Geçtan, 1999:33). Bu noktada bireylerin yaşadığı yalnızlık olgusunun boyutları olduğu ortaya konulmuştur. Bunlar (Sadler \& Johnson, 1980): yalnızlık,

1) Bireyin kendi içsel parçalarıyla temassızlı̆ı̆ından kaynaklanan duygu durumunu ifade eden psikolojik

2) Kendini diğer insanlardan ayıran kendilik algısının oluşturduğu kişiler arası yalnızlık,

3) Başkaları veya grup tarafından dışlanmanın oluşturduğu sosyal yalnızlık,

4) Kültürel kesintiler ile külttürel değişimin oluşturduğu yaşantılardan kaynaklanan kültürel yalnızlık,

5) Tanrı'dan veya doğadan uzaklaşma sonucu oluşan kozmik yalnızlık.

İşyerindeki yalnızlık diğer yalnızlık kavramlarından farklıdır. İşyerindeki yalnızlık; daha çok sosyal çevreden kaynaklanan bir başına bırakma, izole etme ve kendi başına olma halini ifade eder. Yalnızlık ise bireysel özelliklerden kaynaklanır. (Yılmaz \& Aslan, 2013). Günlük hayatta oldukça doyurucu ve sağlıklı ilişkileri olan ve yalnızlık duyguları yaşamayan bir birey, iş ortamında sosyal ilişkiler kurmakta ve sosyal destek almada sıkıntılar yaşayabilmektedir. $\mathrm{Bu}$ durum bireyin iş yaşamında yalnızlık ve dışlanmışlık duyguları yaşamasına neden olabilmektedir (Doğan vd. 2009).

Yalnızlık birbirinden çok farklı bireysel ve örgütsel değişken tarafından şekillendirilmekte ve anlam kazanmaktadır (Bakioğlu \& Korumaz, 2014). Her ne kadar bireyin kendi tercihlerinden veya işyeri ortamındaki sosyal ilişkiler konusundaki tercihlerinden kaynaklanabilmekteyse de işyeri yalnızlığı genel itibariyle istenilir bir durum değildir. İşyerindeki yalnızlığın en belirgin sonuçlarının çalışanın iş veriminin düşmesi ve iş doyumunun azalması olması beklenir (Mercan vd., 2012).

İşyeri yalnızlığının sosyal ve duygusal olmak üzere 2 alt boyutu vardır. İlişkisel anlamda bağ kuramamak ve duygusal kopukluklar yaşamak olarak ifade edilebilen bu işyeri yalnızlığı boyutları bireyler açısından örgütten uzaklaşma, dışlanma ve hatta işten ayrılmalara kadar ulaşabilen sonuçlara sebebiyet verebilir.

\section{3. Örgütsel Dedikodu İşyeri Yalnızlığı İlişsisi}

Resmi yapının içinde resmi olmayan örgüt her zaman vardır. Resmi olmayan örgüt; resmi yapının içinde tanımlananlara bakılmaksızın, örgütte çalışan insanların etkileşiminden, insanların psikolojik ve sosyal ihtiyaçlarından, grupların kendi ilişkileri ve davranış normlarının gelişiminden meydana gelir (Guirdham, 1995:100).

Örgüt içerisinde önlenemez bir dedikodu mekanizmasının varlığı yönetsel anlamda bazı avantajlar sağlamakla birlikte, genel itibariyle kurum mekanizmalarının işleyişini ve sağlığını bozan bir durumdur. Nerede bilgi eksikliği varsa dedikodu oraya üşüşür, sırların yarattığı anlam boşluklarına ise birbiriyle ilgisi olmayan imgeler, çağrışımlar doluşur. Dedikodu, yarım yamalak bilgiyi kategorileştirerek hayali nesnelere dönüştürür ve bildik kavramlarla ilişkilendirerek olup biten hakkında konuşulur hale getirir (Solmaz, 2006). Dolayısıyla dedikodu güven eksikliğinin yaşandığı örgütlerde daha yüksek oranda görülmektedir. Örgüte olan güven eksikliği ise bireylerin aidiyet duygusunu zedeler ve zaman içerisinde çalışanlarda örgüt üyeleriyle paylaşımların azalmasına sebebiyet verir. Paylaşımların azalması ile çalışanlar sosyal ilişkiler ağının dışına itilmeye zorlanır ve sosyal işyeri yalnızlığı denilen kavram ortaya çıkabilir.

Diğer bir taraftan ise insanlar dedikodu yoluyla diğerlerinin hatalarını ve zayıflıklarını keşfedip tartışarak kendilerini daha iyi hissederler (Michelson vd., 2010). Dedikodunun zemin hazırladığı bu durum ise bazı çalışanlar açısından can sıkıcı, ya da kabul edilemez olabilir. Örgütsel dedikoduya maruz kalmak istemeyen çalışanların kendilerini iletişim sisteminin dı̧̧ıa çekmeleriyle ise yine işyeri yalnızlığı- duygusal yalnızlık- söz konusu olabilecektir.

Dolayısıyla kavramsal ve mantıksal bir anlamda değişkenlerimiz arasında mevcut olabilen ilişkinin varlığına dair çalışmamıza konu edilen hipotezlerimiz aşağıdaki şekilde oluşturulmuştur:

H1: Kamu kurumlarında çalışanların örgütsel dedikodu eğilimleri ile sosyal işyeri yalnızlığı (sosyal arkadaşlık) arasında pozitif yönlü bir ilişki vardır.

H2: Kamu kurumlarında çalışanların örgütsel dedikodu eğilimleri ile duygusal işyeri yalnızlı̆̆ı (duygusal yoksunluk) arasında pozitif yönlü bir ilişki vardır. 


\section{Araştırma}

\subsection{Araştırmanın Amacı}

Araştırma amacı kapsamında çalışanların örgütsel dedikodu eğilimlerinin sosyal ve duygusal işyeri yalnızlığı üzerindeki etkisi Şekil 1 'deki araştırma modelinde gösterilmiştir. Bu kapsamda oluşturulan hipotezler "modelde ileri sürülen değişkenler arasında istatistiksel olarak anlamlı bir ilişki olduğu” biçimindedir.

\section{Şekil 1: Araştırma Modeli}

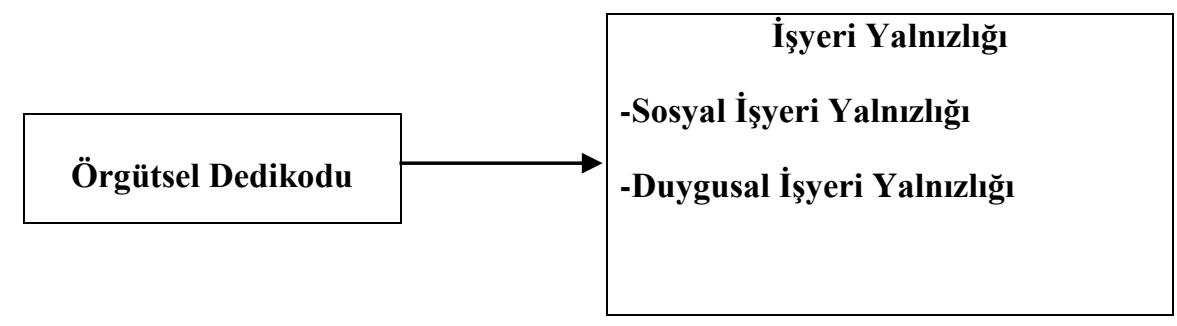

\section{2. Örneklem ve Veri Toplama}

Çalışmamız çalışma sürelerinin uzun ve ilişkilerin daha samimi olması nedenleriyle kamu sektörü çalışanlarından oluşturulan bir örneklem üzerinde gerçekleştirilmiştir. Uşak Belediyesi dâhilinde çalışmakta olan 144 işgören çalışma evrenimizi oluşturmakta olup, çalışmanın güvenilirliğini artırmak amacıyla ve ulaşım imkânlarının uygun olması nedeniyle tamamı çalışma örneklemimiz olarak belirlenmiştir.

Gönderilen anketlerden 124 adedi geri dönmüş ve bunların 21 adedi mükerrer ya da hatalı işaretleme, eksiklik gibi sebeplerle kullanılamaz durumda olduğundan çıkarılmış, geriye kalan 103 adedi ise veri seti olarak kullanılmıştır.

\section{3. ÖIçekler}

Çalışmamızda örgütsel dedikodu kavramıyla ilgili olarak Leblebici, Yıldız \& Karasoy (2009) tarafından geliştirilen 5'li Likert ölçüm tekniğini içeren (1= hiç katılmıyorum ve 5 = tamamen katılıyorum) 19 soruluk ölçek kullanılmıştır.

İş yeri yalnızlığına ilişkin ise Wright vd. (2006) tarafından geliştirilen ve Türk çalışanlar için geçerlilik ve güvenilirlik çalışması yapılmış (Doğan vd, 2009) olan 16 soruluk İş Yaşamında Yalnızlık Ölçeği (İYYÖ) uygulanmıştır. Söz konusu ölçek “Duygusal Yoksunluk ve "Sosyal Arkadaşlık' olmak üzere iki alt boyuttan oluşmaktadır. Ölçeğin özgün şekli yedi basamaklı Likert tipi ölçek olmasına rağmen "Türkçe anlam açısından en fazla beş seçeneğe kadar anlaşılır seçenek” olabileceği savından hareketle Türkçe formun beşli Likert tipine göre hazırlanması yoluna gidilmiştir (Doğan vd, 2009).

\section{4. Ölçeklere İlișkin Geçerlilik ve Güvenilirlik Analizleri}

Araştırmamız çerçevesinde örgütsel dedikodu ve iş yaşamında yalnızlık ölçekleri, daha önce farklı araştırmacılarca gerekli analizler yapıldığı için tarafımızca faktör analizine tabi tutulmamıştır. Ancak elde edilen verilen güvenirliği ve iç tutarlılığını sınamak amacıyla güvenirlik analizi yapılmıştır. Örgütsel dedikodu ölçeğinin toplam güvenilirliği için Cronbach Alfa katsayısı (a) 0.804 iş yaşamında yalnızlık ölçeğinin toplam güvenilirliği için Cronbach Alfa katsayısı ise (a) 0.532 olarak hesaplanmıştır.

Anket formunun, veri tabanına betimleyici faktör analizi uygulayabilme koşulunu ifade eden KaiserMeyer-Olkin örneklem yeterlilik ölçütü 0,730 ve veri tabanından anlamlı faktör çıkarılabileceğini ifade eden küresellik testi oranı (Bartlett test değeri) 1252,553 (p<,000) olarak hesaplanmıştır. Dolayısıyla örneklem büyüklüğümüz yeterlidir ve değişkenler arası sınanabilir bir ilişki mevcuttur. 
Şekil 2: Değişkenlere İlişkin Güvenilirlik Analizleri

\begin{tabular}{|c|c|c|}
\hline Değiş̧ken & Soru Sayısı & İc Tutarlılık Katsayıları ( $\alpha)$ \\
\hline Örgütsel Dedikodu Ölçeği & 19 & 0,804 \\
\hline İş Yaşamında Yalnızlık Ölçeği & 16 & 0,532 \\
\hline Duygusal Yoksunluk & 9 & 0,472 \\
\hline Sosyal Arkadaşlık & 7 & 0,607 \\
\hline
\end{tabular}

\section{Şekil 3. KMO and Barlett's Test}

Kaiser-Meyer-Olkin Measure of Sampling Adequacy.

Approx. Chi-Square

Bartlett's Test of Sphericity df

df

Sig.

\section{Analizler}

Araştırmada elde edilen veriler SPSS (Statistical Package for Social Sciences) for Windows 20.00 Programı kullanılarak analiz edilmiştir. Verileri değerlendirilirken tanımlayıcı istatistiksel metotları (Sayı, Yüzde, Ortalama, Standart sapma) kullanılmıştır.

Araștırmanın bağımlı ve bağımsız değişkenleri arasındaki ilişkiyi Pearson korelasyon, etki ise regresyon analizi ile test edilmiştir. Elde edilen bulgular \%95 güven aralığında \%5 anlamlılık düzeyinde değerlendirilmiştir. Çalışmadan elde edilen demografik faktörlere ilişkin veriler aşağıdaki tabloda gösterilmiştir.

\section{Şekil 3: Demografik Özellikler}

\begin{tabular}{|c|c|c|c|c|c|}
\hline $\begin{array}{c}\text { Ĕğitim } \\
\text { Durumu }\end{array}$ & Sayı & Yüzde & Gelir Durumu & Sayı & Yüzde \\
\hline Lise & 49 & 47,6 & 1001-1499 TL & 52 & 50,42 \\
\hline Önlisans & 20 & 19,4 & 1500-1999 TL & 26 & 25,24 \\
\hline Lisans & 21 & 20,4 & 2000-2999 TL & 19 & 18,4 \\
\hline Lisans $\ddot{U}_{s t \ddot{u}}$ & 13 & 12,6 & 3000-3999 TL & 3 & 2,9 \\
\hline Toplam & 103 & 100 & 4000-4999 TL & 2 & 1,95 \\
\hline Yaş & Sayı & Yüzde & 5000 TL ve Üstü & 1 & 1,0 \\
\hline $18-25$ & 51 & 49,5 & Toplam & 103 & 100 \\
\hline $26-35$ & 27 & 26,2 & Cinsiyet & Sayı & Yüzde \\
\hline $36-45$ & 17 & 16,5 & Erkek & 58 & 56,3 \\
\hline $45+$ & 8 & 7,8 & Kadın & 45 & 43,7 \\
\hline Toplam & 103 & 100 & Toplam & 103 & 100 \\
\hline
\end{tabular}


Şekil 4: İstihdam Özellikleri

\begin{tabular}{|c|c|c|c|c|c|}
\hline İş Tecrübesi & Sayt & Yüzde & $\begin{array}{c}\text { Kamuda Çalışma } \\
\text { Süresi }\end{array}$ & Sayı & Yüzde \\
\hline $0-1$ yll & 20 & 19,4 & 1 yıldan az & 53 & 51,5 \\
\hline $2-5 y l l$ & 39 & 37,9 & $1-3 \mathrm{Yll}$ & 57 & 35,9 \\
\hline 6-10 yll & 28 & 27,2 & 4-7 Yll & 8 & 7,8 \\
\hline $11-20 y l l$ & 10 & 9,7 & 8-11 Yll & 3 & 2,9 \\
\hline 20' den fazla yıl & 6 & 5,8 & 12 yll ve üzeri & 2 & 1,9 \\
\hline Toplam & 103 & 100 & Toplam & 103 & 100 \\
\hline & & & $\begin{array}{c}\text { Kurumda Çalışma } \\
\text { Süresi } \\
\end{array}$ & Sayt & Yüzde \\
\hline & & & 1 Ylldan az & 51 & 49,5 \\
\hline & & & $1-5 \mathrm{Yll}$ & 38 & 36,9 \\
\hline & & & 6-10 Yll & 8 & 7,8 \\
\hline & & & $11-15 \mathrm{Yll}$ & 3 & 2,9 \\
\hline & & & 21 Yll ve üzeri & 3 & 2,9 \\
\hline & & & Toplam & 103 & 100 \\
\hline
\end{tabular}

Şekil 5: Çalışanların Cinsiyet Durumuna Göre İşyerinde Yalnızlık Ölçeği Boyutlarının Değerlendirilmesi Independend Sample Test

Group Statistics

\begin{tabular}{|l|l|r|r|r|r|}
\hline & Cinsiyet & \multicolumn{1}{|c|}{ N } & \multicolumn{1}{|c|}{ Mean } & \multicolumn{1}{|c|}{ Std. Deviation } & Std. Error Mean \\
\hline Sosyal__ Erkek & 58 & 3,7414 &, 80154 &, 10525 \\
Arkadaşlık & Kadın & 45 & 3,7000 &, 91949 &, 13707 \\
Duygusal__ & Erkek & 58 & 3,7241 &, 85928 &, 11283 \\
Yoksunluk & Kadın & 45 & 3,5889 &, 66818 &, 09961 \\
& & & & & \\
\hline
\end{tabular}




\begin{tabular}{|c|c|c|c|c|c|c|}
\hline & & \multicolumn{5}{|c|}{ Independent Samples Test } \\
\hline & & \multicolumn{2}{|c|}{$\begin{array}{l}\text { Levene's Test for Equality of } \\
\text { Variances }\end{array}$} & \multirow[b]{2}{*}{$t$} & \multirow[b]{2}{*}{ df } & \multirow[b]{2}{*}{ Sig. (2-tailed) } \\
\hline & & $\mathrm{F}$ & Sig. & & & \\
\hline \multirow[t]{2}{*}{ Sosyal_Arkadaşlık } & $\begin{array}{l}\text { Equal variances } \\
\text { assumed }\end{array}$ & \multirow[t]{2}{*}{, 094} & \multirow[t]{2}{*}{, 760} & .244 & 101 & 808 \\
\hline & $\begin{array}{l}\text { Equal variances not } \\
\text { assumed }\end{array}$ & & & .239 & 87,657 &, 811 \\
\hline \multirow[t]{2}{*}{ Duygusal_Yoksunluk } & $\begin{array}{l}\text { Equal variances } \\
\text { assumed }\end{array}$ & \multirow[t]{2}{*}{7,164} & \multirow[t]{2}{*}{, 009} & 871 & 101 &, 386 \\
\hline & $\begin{array}{l}\text { Equal variances not } \\
\text { assumed }\end{array}$ & & & 899 & 100,998 &, 371 \\
\hline
\end{tabular}

Şekil 6: Çalışanların Yaşlarına Göre İşyerinde Yalnızlık Ölçeği Boyutlarının Değerlendirilmesi OneWay ANOVA Test

\begin{tabular}{|c|c|c|c|c|c|c|}
\hline \multicolumn{7}{|c|}{ ANOVA } \\
\hline & & $\begin{array}{l}\text { Sum of } \\
\text { Squares }\end{array}$ & $\mathrm{df}$ & $\begin{array}{l}\text { Mean } \\
\text { Square }\end{array}$ & $\mathrm{F}$ & Sig. \\
\hline \multirow{4}{*}{$\begin{array}{l}\text { Sosyal_ } \\
\text { Arkadaşl1k }\end{array}$} & $\begin{array}{l}\text { Between } \\
\text { Groups }\end{array}$ & 1,617 & 3 & ,539 & ,739 & ,531 \\
\hline & Within & 7004 & & & & \\
\hline & Groups & $|2,24|$ & 99 &,$/ 30$ & & \\
\hline & Total & 73,864 & 102 & & & \\
\hline \multirow{5}{*}{$\begin{array}{l}\text { Duygusal_ } \\
\text { Yoksunluk }\end{array}$} & Between & 1127 & 3 & 376 & 609 & 611 \\
\hline & Groups & & & & & \\
\hline & Within & 61067 & 00 & 617 & & \\
\hline & Groups & $61,06 /$ & 99 & ,617, & & \\
\hline & Total & 62,194 & 102 & & & \\
\hline
\end{tabular}

Şekil 7: Çalışanların İş Tecrübelerine Göre İşyerinde Yalnızlık Ölçeği Boyutlarının Değerlendirilmesi OneWay ANOVA Test

ANOVA

\begin{tabular}{|c|c|c|c|c|c|c|}
\hline & & $\begin{array}{l}\text { Sum of } \\
\text { Squares }\end{array}$ & $\mathrm{df}$ & $\begin{array}{l}\text { Mean } \\
\text { Square }\end{array}$ & $\mathrm{F}$ & Sig. \\
\hline \multirow{5}{*}{$\begin{array}{l}\text { Sosyal_ } \\
\text { Arkadaşlık }\end{array}$} & Between & 1,780 & 4 & ,445 & ,605 & ,660 \\
\hline & Groups & & & & & \\
\hline & Within & 72084 & 98 & 736 & & \\
\hline & Groups & & & & & \\
\hline & Total & 73,864 & 102 & & & \\
\hline Duygusal_ & Between & 2045 & 4 & 736 & 218 & 200 \\
\hline Yoksunluk & Groups & 2,945 & 4 &, 150 & 1,218 & , \\
\hline
\end{tabular}




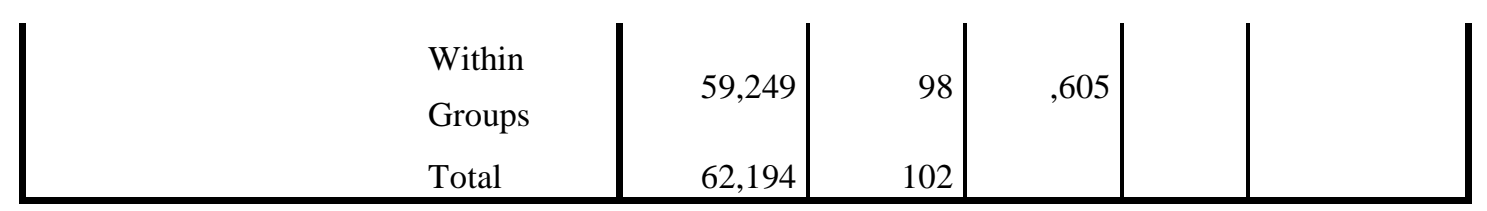

Şekil 8: Çalsşanların Gelir Durumlarına Göre İşyerinde Yalnızlık Ölçeği Boyutlarının Değerlendirilmesi OneWay ANOVA Test

ANOVA

\begin{tabular}{|c|c|c|c|c|c|c|}
\hline & & $\begin{array}{l}\text { Sum of } \\
\text { Squares }\end{array}$ & $\mathrm{df}$ & $\begin{array}{l}\text { Mean } \\
\text { Square }\end{array}$ & $\mathrm{F}$ & Sig. \\
\hline \multirow{5}{*}{$\begin{array}{l}\text { Sosyal__ } \\
\text { Arkadaşlık }\end{array}$} & Between & 10,676 & 6 & 1,779 & 2,703 & ,018 \\
\hline & $\mathrm{Wi}$ & & & & & \\
\hline & Groups & 63,188 & 96 & 658 & & \\
\hline & Total & 73,864 & 102 & & & \\
\hline & Between & 3,787 & 6 & .631 & 1,037 & ,406 \\
\hline \multirow{4}{*}{$\begin{array}{l}\text { Duygusal } \\
\text { _Yoksunluk }\end{array}$} & Groups & & & & & \\
\hline & Within & 58,407 & 96 & .608 & & \\
\hline & Groups & & & & & \\
\hline & Total & 62,194 & 102 & & & \\
\hline
\end{tabular}

Çalışanların cinsiyet, yaş, iş tecrübesi durumlarının iş yaşamında yalnızlık ölçeği alt boyutları bağlamında etkili olup olmadığı yukarıdaki tablolarda ayrıntıları gösterilen One Way Anova testleri ile ortaya konulmuştur. Yapılan analizler neticesinde ölçeği oluşturan alt boyutlardan hiç birisi için görüşülenlerin cinsiyet, yaş ve iş tecrübesi niteliklerinin grupların anlamlılık düzeyinde bir farklılık oluşturmadığı ortaya çıkmıştır. Bunu tabloda ki "f" değeri ve "sig" değerleri göstermektedir (sig "p" anlamlılık düzeyini göstermektedir). (p>0,05)

Bununla beraber çalışanların aylık gelir durumlarının iş yaşamında yalnızlık ölçeği alt boyutları bağlamında etkili olup olmadığına ilişkin yapılan analizler neticesinde ölçeği oluşturan alt boyutlardan Duygusal Yoksunluk alt boyutu için görüşülenlerin aylık gelir gruplarının anlamlılık düzeyinde bir farklılık oluşturmadığı ortaya çıkmıştır. Sosyal Arkadaşlık alt boyutu için ise, görüşülenlerin aylık gelir gruplarının anlamlılık düzeyinde bir farklılık oluşturduğu ortaya çıkmıştır. Bunu tabloda ki "f" değeri ve "sig" değerleri göstermektedir (sig "p" anlamlılık düzeyini göstermektedir). ( $\mathrm{p}<0,05)$ Farklılı̆̆ın kaynaklandığ 1 grubu belirlemeye yönelik yapılan PostHoc testine göre 1001- 1499 TL arasında gelir düzeyine sahip bireylerin sosyal işyeri yalnızlığı bakımından diğerlerinden farklı olduğu görülmüş olup, bu durum maddi yetersizliklerin sosyalleşmenin önündeki etkisini ortaya koymaktadır.

\section{Şekil 9: Örgütsel Dedikodu Ölçeği One-Sample Test}

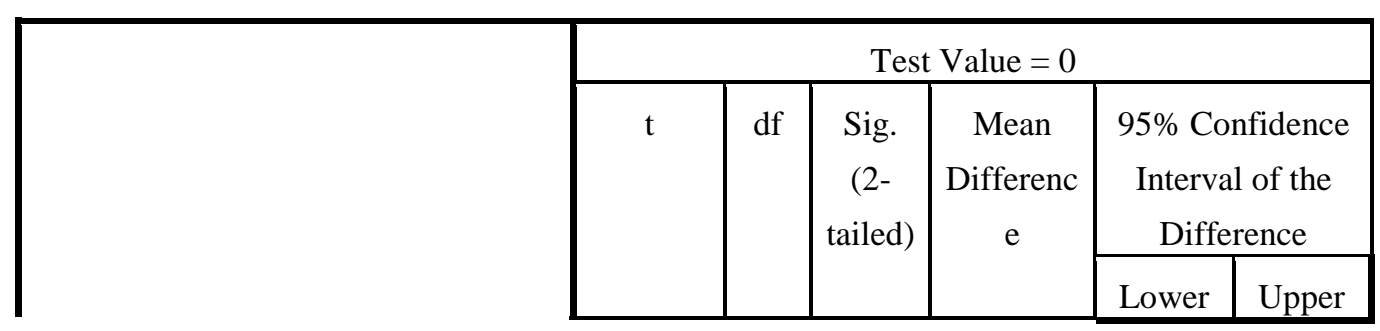




\begin{tabular}{|c|c|c|c|c|c|c|}
\hline $\begin{array}{l}\text { Herkesin_bazen_dedikodu_yaptığını } \\
\text { _düşünüyorum }\end{array}$ & 29,043 & 102 &, 000 & 3,46602 & 3,2293 & 3,7027 \\
\hline Herkes_dedikodu_yapar & 31,049 & 102 &, 000 & 3,44660 & 3,2264 & 3,6668 \\
\hline İyi_insanlar_da_dedikodu_yapar & 32,746 & 102 &, 000 & 3,52427 & 3,3108 & 3,7377 \\
\hline İşyerinde_dedikodu_kaçınılmazdır & 34,828 & 102 &, 000 & 3,65049 & 3,4426 & 3,8584 \\
\hline $\begin{array}{l}\text { Dedikodu_yaparım_ama_her_konuda } \\
\text { _değil }\end{array}$ & 29,184 & 102 &, 000 & 3,28155 & 3,0585 & 3,5046 \\
\hline Dedikodu_bir_iletişim_biçimidir & 26,553 & 102 &, 000 & 3,10680 & 2,8747 & 3,3389 \\
\hline Dedikodu_sadece_eleştirmektir & 26,731 & 102 &, 000 & 3,02913 & 2,8044 & 3,2539 \\
\hline $\begin{array}{l}\text { Dedikodu_iki_kişinin_üçüncü_kişi_h } \\
\text { akkında_konuşmasıdır }\end{array}$ & 34,429 & 102 &, 000 & 3,62136 & 3,4127 & 3,8300 \\
\hline $\begin{array}{l}\text { Dedikodu_insanların_psikolojik_açıd } \\
\text { an_rahatlamalarına_yardımcı_olur }\end{array}$ & 29,751 & 102 &, 000 & 3,02913 & 2,8272 & 3,2311 \\
\hline $\begin{array}{l}\text { Dedikodudan_uzaklaştıkça_işyerinde } \\
\text { olup_bitenlerden_uzak_kaldığımı_h } \\
\text { issederim }\end{array}$ & 28,625 & 102 &, 000 & 3,08738 & 2,8734 & 3,3013 \\
\hline $\begin{array}{l}\text { Dedikodu_sayesinde_rakiplerimin_d } \\
\text { urumu_hakkında_bilgi_alırım }\end{array}$ & 28,641 & 102 &, 000 & 3,15534 & 2,9368 & 3,3739 \\
\hline $\begin{array}{l}\text { İşyerinde_dedikodu_kariyer_yükselt } \\
\text { menin_bir_yoludur }\end{array}$ & 22,037 & 102 &, 000 & 2,81553 & 2,5621 & 3,0690 \\
\hline Hiyerarşi_arttıkça_dedikodu_artar & 27,966 & 102 & ,000 & 3,23301 & 3,0037 & 3,4623 \\
\hline
\end{tabular}

Araştırmamızın örneklem grubuna çalışan sesi ölçeği maddeleri sunulmuş ve puanlamaları talep edilmiştir. Uygulama sonrasında ölçek maddelerine verilen ortalama puanlar belirlenmiştir. Bu çerçevede özellikle en yüksek ortalama puan 'İşyerinde dedikodu kaçınılmazdır' maddesine ve ' Dedikodu iki kişinin üçüncü kişi hakkında konuşmasıdır' maddesine yapılmıştır. Diğer maddelere yapılan puanlamalar hemen hemen aynı düzeyde iken en düşük puanı alan madde ise 'İşyerinde dedikodu kariyer yükseltmenin bir yoludur' maddesidir. 
Şekil 10: İşyerinde Yalnızlık Ölçeği One-Sample Test

\begin{tabular}{|c|c|c|c|c|c|c|}
\hline & \multicolumn{6}{|c|}{ Test Value $=0$} \\
\hline & \multirow[t]{2}{*}{$\mathrm{t}$} & \multirow[t]{2}{*}{ df } & \multirow[t]{2}{*}{$\begin{array}{l}\text { Sig. }(2- \\
\text { tailed) }\end{array}$} & \multirow[t]{2}{*}{$\begin{array}{c}\text { Mean } \\
\text { Difference }\end{array}$} & \multicolumn{2}{|c|}{$\begin{array}{c}95 \% \text { Confidence Interval of } \\
\text { the Difference }\end{array}$} \\
\hline & & & & & Lower & Upper \\
\hline $\begin{array}{l}\text { İş_ortamında_baskı_altı } \\
\text { ndayken_iş_arkadaşları } \\
\text { m_tarafindan_yalnı__bır } \\
\text { akıldığımı_hissederim }\end{array}$ & 24,124 & 102 &, 000 & 2,80583 & 2,5751 & 3,0365 \\
\hline $\begin{array}{l}\text { Çoğunlukla_iş_arkadaşl } \\
\text { arımın_bana_mesafeli_d } \\
\text { urduklarını_hissediyoru } \\
\mathrm{m}\end{array}$ & 26,342 & 102 &, 000 & 2,82524 & 2,6125 & 3,0380 \\
\hline $\begin{array}{l}\text { Birlikte_çalıştığım_insa } \\
\text { nlarla_arama_mesafe_k } \\
\text { oyduğumu_hissediyoru } \\
\text { m }\end{array}$ & 27,316 & 102 &, 000 & 3,06796 & 2,8452 & 3,2907 \\
\hline $\begin{array}{l}\text { Kendimi_iş_arkadaşları } \\
\text { mdan_duygusal_olarak_ } \\
\text { uzak_hissediyorum }\end{array}$ & 28,868 & 102 &, 000 & 3,15534 & 2,9385 & 3,3721 \\
\hline $\begin{array}{l}\text { İş_yerimdeki_ilişkilerim } \\
\text { den_memnunum }\end{array}$ & 39,923 & 102 &, 000 & 3,66990 & 3,4876 & 3,8522 \\
\hline $\begin{array}{l}\text { Çalıştığım_iş_yerinde_d } \\
\text { ostluk_anlayışı_hakimdi } \\
\text { r }\end{array}$ & 38,071 & 102 &, 000 & 3,66019 & 3,4695 & 3,8509 \\
\hline $\begin{array}{l}\text { İş_arkadaşlarımla_birlik } \\
\text { teyken_çoğu_zaman_ke } \\
\text { ndimi_dışlanmış_hissed } \\
\text { iyorum }\end{array}$ & 25,034 & 102 &, 000 & 2,91262 & 2,6818 & 3,1434 \\
\hline $\begin{array}{l}\text { İş_yerinde_çoğu_zaman } \\
\text { _diğer_çalışanlarla_birli } \\
\text { kte_aramda_bir_kopukl } \\
\text { uk_hissederim }\end{array}$ & 23,712 & 102 &, 000 & 2,97087 & 2,7224 & 3,2194 \\
\hline $\begin{array}{l}\text { İş_yerindeyken_kendim } \\
\text { i_genel_bir_boşluk_duy } \\
\text { gusu_içinde_hissederim }\end{array}$ & 6,737 & 102 &, 000 & 3,50485 & 2,4729 & 4,5368 \\
\hline $\begin{array}{l}\text { İş_yerinde_sosyal_ilişki } \\
\text { lerim_vardır }\end{array}$ & 37,275 & 102 &, 000 & 3,58252 & 3,3919 & 3,7732 \\
\hline $\begin{array}{l}\text { İş_yerimdeki_sosyal_et } \\
\text { kinliklere_katıllırım }\end{array}$ & 39,119 & 102 &, 000 & 3,73786 & 3,5483 & 3,9274 \\
\hline
\end{tabular}




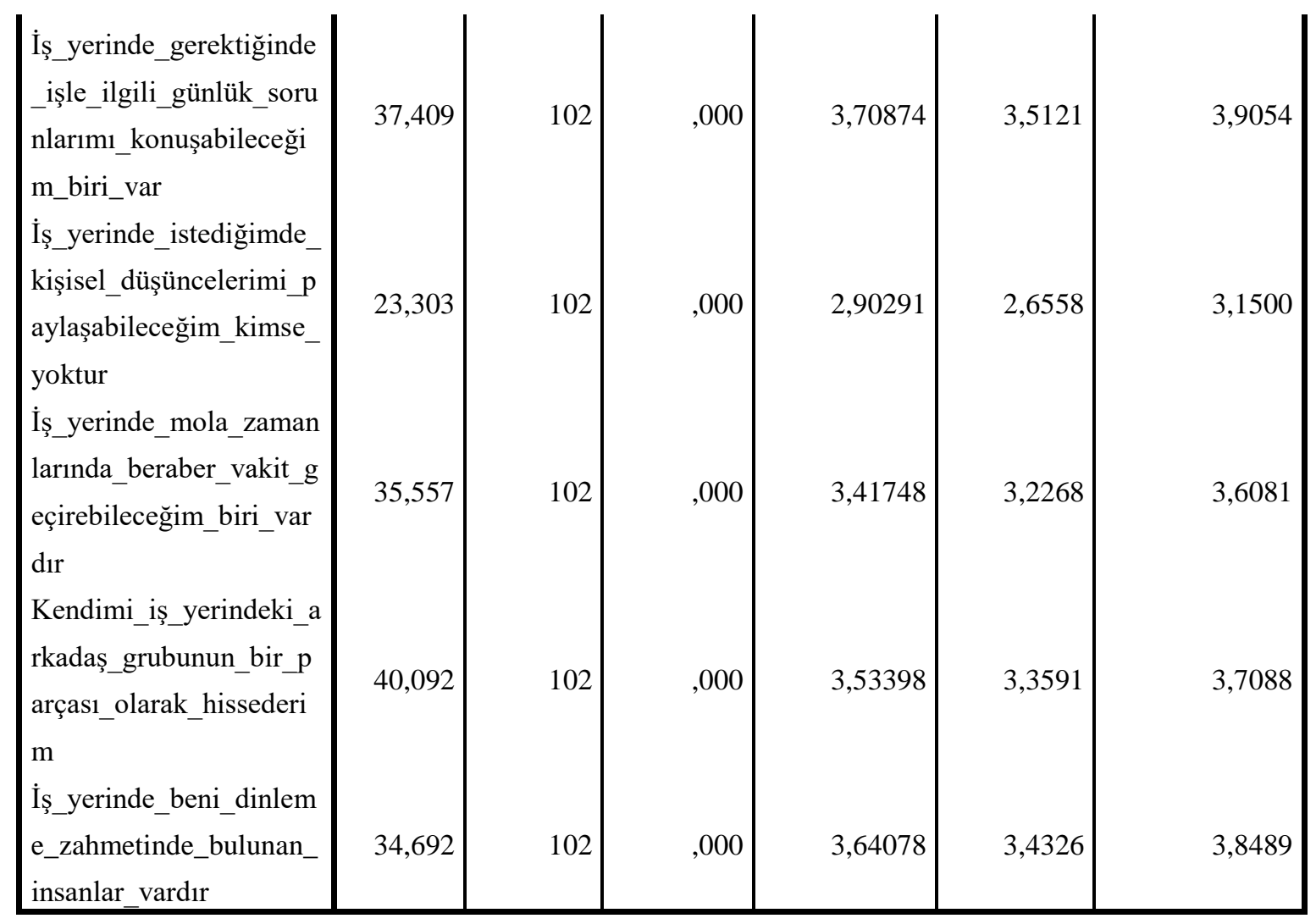

Araştırmamızın örneklem grubuna işyeri yalnızlığı ölçeği maddeleri sunulmuş ve bunların puanlanması istenmiştir. Uygulama sonrasında ölçek maddelerine verilen ortalama puanlar belirlenmiştir. Bu çerçevede en yüksek ortalama puan 'İş yerimdeki sosyal etkinliklere katılırım' ve ‘İş yerinde gerektiğinde işle ilgili günlük sorunlarımı konuşabileceğim biri var' maddelerine yapılmıştır. Diğer maddelere yapılan puanlamalar hemen hemen aynı düzeyde karşımıza çıkarken en düşük ortalama puana sahip olan madde 'İş ortamında baskı altındayken iş arkadaşlarım tarafından yalnız bırakıldığımı hissederim’ maddesidir.

Ölçeğin alt boyutları bağlamında bir değerlendirme yapılacak olursa öncelikle 1-9'ncu maddeler 'Duygusal Yoksunluk' alt boyutunu oluşturmaktadır. Bu boyut içinde en düşük ortalama puan 'İş ortamında bask1 altındayken iş arkadaşlarım tarafından yalnız bırakıldığımı hissederim' maddesine yapılmıştır. 'Sosyal Arkadaşık' alt boyutu 10-16'ncı önermelerden oluşmaktadır. Bu boyut içinde en düşük ortalama puan 'İş yerinde istediğimde kişisel düşüncelerimi paylaşabileceğim kimse yoktur' maddesine yapılmıştır.

\section{Hipotez Testleri}

Örgütsel dedikodunun iş yeri yalnızlığı üzerine etkisini ortaya çıkartma amacıyla gerçekleştirilmiş olan çalışmamızda iki hipotezimiz bulunmaktadır. Bu hipotezlerin her biri yapılan korelasyon ve regresyon analizleri ile test edilmiş ve yorumlanmıştır.

H1: Kamu kurumlarında çalışanların örgütsel dedikodu eğilimleri ile sosyal işyeri yalnızlı̆̆ arasında pozitif yönlü bir ilişki vardır.

\section{Correlations}

\begin{tabular}{|ll|l|l|}
\hline & & ÖDÖ & Sosyal_Arkadaşlik \\
\hline \multirow{4}{*}{ ÖDÖ } & Pearson & &, $245^{*}$ \\
& Correlation & 1 &, 013 \\
& Sig. (2-tailed) & & 103 \\
& $\mathrm{~N}$ & 103 &
\end{tabular}




\begin{tabular}{|ll|l|l|} 
& Pearson &, $245^{*}$ & 1 \\
Sosyal & Correlation & & \\
Arkadaşlik & Sig. (2-tailed) &, 013 & \\
& $\mathrm{~N}$ & 103 & 103 \\
\hline
\end{tabular}

*. Correlation is significant at the 0.05 level (2-tailed).

Örgütsel dedikodu eğilimleri çalışanların işyeri yalnızlığı ölçeği sosyal arkadaşlık alt boyutuna anlamlı bir etki yapmaktadır. ( $\mathrm{p}>0,05)$ H1 hipotezi kabul edilir. $r=0,245$ pozitif yönlü ilişkinin gücü çok zayıftır.

\section{Coefficients $^{\mathrm{a}}$}

\begin{tabular}{|c|c|c|c|c|c|}
\hline \multirow[t]{2}{*}{ Model } & \multicolumn{2}{|c|}{$\begin{array}{c}\text { Unstandardized } \\
\text { Coefficients }\end{array}$} & \multirow{2}{*}{$\begin{array}{c}\begin{array}{c}\text { Standardized } \\
\text { Coefficients }\end{array} \\
\text { Beta }\end{array}$} & \multirow[t]{2}{*}{$\mathrm{t}$} & \multirow[t]{2}{*}{ Sig. } \\
\hline & $\mathrm{B}$ & Std. Error & & & \\
\hline (Constant) & 2,166 &, 524 & & 4,132 &, 000 \\
\hline $\begin{array}{l}\text { Sosyal_ } \\
\text { Arkadaşl1k }\end{array}$ & ,349 &, 137 & ,245 & 2,542 & 013 \\
\hline
\end{tabular}

a. Dependent Variable: ÖDÖ

Örgütsel dedikodu eğilimlerindeki her birim değişim çalışanların sosyal arkadaşlık boyutuna 0,349 birim etki etmektedir.

H2. Kamu kurumlarında çalışanların örgütsel dedikodu eğilimleri ile duygusal işyeri yalnızlığı arasında pozitif yönlü bir ilişki vardır.

\section{Correlations}

\begin{tabular}{|c|c|c|c|}
\hline & & $\begin{array}{l}\text { Duygusal_ } \\
\text { Yoksunluk }\end{array}$ & ÖDÖ \\
\hline \multirow{4}{*}{$\begin{array}{l}\text { Duygusal_- } \\
\text { Yoksunluk }\end{array}$} & Pearson & 1 & $343^{* *}$ \\
\hline & Correlation & 1 & \\
\hline & Sig. (2-tailed) & & ,000 \\
\hline & $\mathrm{N}$ & 103 & 103 \\
\hline \multirow{4}{*}{ ÖDÖ } & Pearson & $312^{* * *}$ & \\
\hline & Correlation &, 345 & 1 \\
\hline & Sig. (2-tailed) &, 000 & \\
\hline & $\mathrm{N}$ & 103 & 103 \\
\hline
\end{tabular}

**. Correlation is significant at the 0.01 level (2-tailed).

Örgütsel dedikodu eğilimleri çalışanların sosyal yalnızlık ölçeği duygusal yoksunluk alt boyutuna pozitif bir etki yapmaktadır. ( $p>0,05) \mathbf{H 2}$ hipotezi kabul edilir. $r=0,343$ pozitif yönlü ilişkinin gücü zayıftır.

\section{Coefficients $^{\mathrm{a}}$}




\begin{tabular}{|c|c|c|c|c|c|c|}
\hline \multirow{2}{*}{\multicolumn{2}{|c|}{ Model }} & \multicolumn{2}{|c|}{$\begin{array}{c}\text { Unstandardized } \\
\text { Coefficients }\end{array}$} & \multirow{2}{*}{$\begin{array}{c}\begin{array}{c}\text { Standardized } \\
\text { Coefficients }\end{array} \\
\text { Beta }\end{array}$} & \multirow[t]{2}{*}{$\mathrm{t}$} & \multirow[t]{2}{*}{ Sig. } \\
\hline & & $\mathrm{B}$ & Std. Error & & & \\
\hline \multirow[b]{2}{*}{1} & (Constant) & 1,517 &, 543 & & 2,792 & ,006 \\
\hline & $\begin{array}{l}\text { Duygusal_Yo } \\
\text { ksunluk }\end{array}$ &, 532 &, 145 &, 343 & 3,668 & ,000 \\
\hline
\end{tabular}

a. Dependent Variable: ÖDÖ

Örgütsel dedikodu eğilimlerindeki her birim değişim çalışanların duygusal yoksunluk boyutuna 0,532 birim etki etmektedir.

\section{Sonuç}

Hangi sebeple ve hangi tür olursa olsun (sosyal, duygusal, kozmik, bireysel, vs.) işyeri yalnızlığı kurumlar açısından yıkıcı sonuçlar doğurabilen, çalışanların iş tatminlerini azaltmak suretiyle verimliliklerini buna bağlı olarak da makro açıdan bakıldığında işletmenin başarısını ve işyeri huzurunu bozan bir olgudur. Çalışmamız aracılığıyla örgütlerde dedikodu eğiliminin çalışanları sosyal (ilişkisel anlamda bă̆ kuramamak) ve duygusal (duygusal kopukluklar yaşamak) işyeri yalnızlığına sürüklediği ve bu etkinin duygusal yalnızlık açısından daha yüksek olduğu görülmüştür.

Dolayısıyla örgütlerde dedikodunun önüne geçilmesine yönelik bazı tedbirler alınarak çalışanları verimsizliğe, çatışmaya ve daha ileri boyutlarda iş devamsızlığı ve hatta işten ayrılmaya yönelten işyeri yalnızlığının engellenmesi sağlanmalıdır. Bu tedbirler arasında; yönelik)

- Çalışanlarla şeffaf ve açık iletişim ortamı sağlanması (dedikodunun iletişim rolünün önüne geçilmesine

- Çalışanların birbirlerinin özel hayatlarına ve farklılıklarına saygı duymasını sağlamak ve istenmeyen durumları engellemeye yönelik yaptırımlar uygulamak

- İşgücünde rotasyon uygulamaları yaparak birimler arasında kaynaşmayı sağlamak (yıkıcı dedikoduyu engellemeye yönelik)

- Çalışanların işyeri dışında paylaşımlarını artırmaya yönelik mesai dışı grup aktiviteleri ve ziyaretler gerçekleştirmek (sevgi ve saygıyı artırarak, yıkıcı dedikoduyu önlemeye yönelik)

Sayılabilecektir.

\section{Kaynakça}

Akdoğan, A., Mirap, S., \& Cingöz, A. (2009) Işsörenlerin dedikoduya inanma düzeyleri ve dedikodunun amaçlarina ilişkin algilamalari: örgütsel ve bireysel değişkenler açisindan bir inceleme. 17. Ulusal Yönetim ve Organizasyon Kongresi Bildiriler Kitabı (ss: 17-25). Eskişehir Osmangazi Üniversitesi Yayını.

Bakioğlu, A., \& Korumaz, M. (2014). Öğretmenlerin okulda yalnızlıklarının kariyer evrelerine göre incelenmesi. Eğitim Bilimleri Dergisi, 39(1), 25-54.

Doğan, T., Çetin B., \& Sungur, M. Z. (2009). İş yaşamında yalnızlık ölçeği türkçe formunun geçerlilik ve güvenilirlik çalışması. Anadolu Psikiyatri Dergisi, 10 (1), 271-277.

Ernst, J. M., \& Cacioppo, J. T. (1999). Lonely hearts: Psychological perspectives on loneliness. Applied and Preventive Psychology, 8(1), 1-22.

Eroğlu, E. (2005). Yöneticilerin dedikodu ve söylentiye yönelik davranış biçimlerinin belirlenmesi (Arfor Taşıma Hizmetleri A.Ş.'de bir uygulama). Manas Üniversitesi Sosyal Bilimler Dergisi, 13(1), 203-218.

Geçtan, E. (1999). Modern Life And Abnormal Behaviors, İstanbul: Remzi Yayınevi.

Guirdham, M. (1995). Interpersonal Skills At Work, New Jersey USA: Pretice Hall.

Leblebici, D. N., Yıldız, H. H.,\& Karasoy, A. (2009). Örgütsel yaşamda dedikodunun algılanışı ve araçsallığı. Selçuk Üniversitesi Sosyal Ve Ekonomik Araştırmalar Dergisi, 18, 561-574. 
Mercan, N., Oyur, E., Alamur, B., Gül, S., \& Bengül, S. (2012). İşyeri yalnızlığı ve sosyal fobi arasındaki ilişkiye yönelik bir araştırma. Organizasyon Ve Yönetim Bilimleri Dergisi, 4 (1), 214-226.

Michelson, G., Iterson, A., \& Waddington, K. (2010). Gossip in organizations: Contexts, consequences, and controversies. Group \& Organization Management, 35(4), 371-390.

Rosnow, R. L. (1977). Gossip and marketplace psychology. Journal Of Communication, 27 (1), 158-163.

Sadler, W. A., \& Johnson, T. B. (1980). From loneliness to anomia. In J. Hartog, J.R. Audy, Y.A. Cohen (Eds.), The Anotomy Of Loneliness (34-64). New York: International Universities Press.

Schermerhon, J. R., Hunt, J. G., \& Osborn, R. N. (2000). Organizational Behavior. Londra: John Willey\&Sons Inc.

Solmaz, B. (2006). Söylenti ve dedikodu yönetimi. Selçuk Üniversitesi Sosyal Bilimler Dergisi, 16, 563-575.

Şişman, M., \& Turan, S. (2004). Bazı örgütsel değişkenler açısından çalışanların iş doyumu ve sosyal - duygusal yalnızlık düzeyleri (Meb şube müdür adayları üzerinde bir araştırma). Osmangazi Üniversitesi Sosyal Bilimler Dergisi, 5(1), 117-128.

Türk Dil Kurumu. (2011). Büyük Türkçe sözlük. Erişim Tarihi:11.10.2016, http://www.tdk.gov.tr/

Thomas, S. A., \& Rozell E. J. (2007). Gossip and nurses: Malady or remedy? Health Care Management, 26(2), 111-115.

Yılmaz, A., \& Aslan, H. (2013). Öğretmenlerin işyerindeki yalnızlıkları ve yaşam doyumları arasındaki ilişkinin incelenmesi. Pegem Ĕ̆itim Ve Öğretim Dergisi, 3(3), 2013, 59-69.

Wright, S. L, Burt, C. D. B. , \& Strongman, K. T. (2006). Loneliness in the workplace: Construct definition and scale development. N Z Journal Of Psychology, 35, 59-68. 